E3S Web of Conferences 1, 11001 (2013)

DOI: $10.1051 / \mathrm{e} 3$ sconf/20130111001

(c) Owned by the authors, published by EDP Sciences, 2013

\title{
Element content in cultured and wild sea bass (Dicentrarchus labrax) from the Adriatic Sea
}

\author{
$\underline{\text { P. Žvab Rožič }}{ }^{1}$, T. Dolenec ${ }^{1}$, B. Baždarić ${ }^{2}$, V. Karamarko ${ }^{2}$, G. Kniewald ${ }^{3}$ and M. Dolenec $^{1}$ \\ ${ }^{1}$ University of Ljubljana, Faculty of Natural Sciences and Engineering, Department of Geology, Aškerčeva 12, 1000 \\ Ljubljana, SLOVENIA, petra.zvab@guest.arnes.si \\ ${ }^{2}$ Dalmar d.o.o., Jadranska cesta 4, Pakoštan, CROATIA \\ ${ }^{3}$ Ruđer Bošković Institute, Bjienička 54, Zagreb, CROATIA
}

\begin{abstract}
The aim of this study was to determine the levels of potentially toxic elements in cultured and wild fish tissues and to assess their risk for human health. For this purpose, sea bass specimens (Dicentrarchus labrax) were sampled in selected fish farm and three other locations along the eastern Adriatic coast. Ranges of element concentrations in sea bass muscles were 1.60-4.46 ppm for As, 0.001-0.079 ppm for $\mathrm{Cd}, 0.14-49.10 \mathrm{ppm}$ for $\mathrm{Cr}, 1.38-4.85 \mathrm{ppm}$ for $\mathrm{Cu}, 0.11-1.31 \mathrm{ppm}$ for $\mathrm{Hg}, 0.01-0.65 \mathrm{ppm}$ for $\mathrm{Pb}$ and 21.9$136.0 \mathrm{ppm}$ for $\mathrm{Zn}$. Mean $\mathrm{Cd}, \mathrm{Cr}, \mathrm{Cu}, \mathrm{Hg}, \mathrm{Pb}$, and $\mathrm{Zn}$ concentrations in commercially interesting cultured fish samples were below the permissible levels, while mean As values slightly exceed those limits. In wild fishes mean $\mathrm{Cd}, \mathrm{Cu}, \mathrm{Pb}$ and $\mathrm{Zn}$ concentrations were below the recommended limits, for $\mathrm{As}, \mathrm{Cr}$ and $\mathrm{Hg}$ the mean values were higher. The smallest cultured sea bass samples showed $\mathrm{As}, \mathrm{Cr}, \mathrm{Pb}$, and $\mathrm{Zn}$ concentrations exceeding the recommended limits but values decreased with fish size. Therefore, the metal concentrations in commercial fishes showed no threat for human consumption.
\end{abstract}

Key words: Element content, cultured and wild fish, sea bass, Adriatic Sea

\section{Introduction}

Among several different contaminants, metals are recognized as one of the greatest threats to organisms due to their persistence and possible bioaccumulation and biomagnification in the food chain (Demirak et al., 2006; Uysal et al., 2009). Some metals as mercury (Hg), lead $(\mathrm{Pb})$, and cadmium $(\mathrm{Cd})$ are considered to be very dangerous, while some other essential elements, such as copper $(\mathrm{Cu})$, nickel $(\mathrm{Ni})$, chromium $(\mathrm{Cr})$, and zinc $(\mathrm{Zn})$, can also cause toxic effects at excessively elevated values (Cid et al., 2001 and references therein). Food presents the main and a constant source of potentially toxic trace metals in different parts of human body and can cause damage in many of its basic systems (renal, cardiovascular, gastrointestinal, endocrine, nervous, etc. (Cid et al., 2001 and references therein). In Mediterranean countries, especially in coastal areas, human nutrition is highly represented by sea products including fishes. Therefore, the determination of trace metals in fish tissues is necessary. Numerous researches focused to investigation of potentially toxic metals in marine organisms as well as their potential sources (sea water, food) (Ersoy et al., 2006; Burger et al., 2007;
Dural et al., 2007; Biladžić et al., 2011; Fallah et al., 2011; Mieiro et al., 2011; Percın et et al., 2011 and many others).

In our study, levels of trace metal contamination of cultured and wild sea bass were determined. The investigation focused (1) in assess the differences between cultured and wild specimens, (2) to ascertain the possible differences between different fish sizes and (3) to observe possible risk for human health (measured values were compared with guidelines proposed by various authorities).

\section{Materials and Methods}

Sea bass samples were collected in fish farm near Vrgada Island (Central Adriatic) and three coastal locations in the Adriatic Sea: Korčula Island, Pirovac Bay, and Savudrija (northern Istra Peninsula). The observed fish farm was located around 4 nautical miles from the mainland, south of Vrgada Island, which is located in Murter Sea between Zadar and Šibenik (Croatia). The farm produced about 550 tons of fish (sea bass and sea bream) annually. Production ran throughout the whole year, with new generations being born between April and July. During 
the winter the amount of feed given was obviously smaller than during the summer, when the breeding of fishes was highest.

Korčula Island is located in the southern part of the Central Adriatic Sea between Split and Dubrovnik. Samples were collected at the western side of the island orientated towards the open sea. Pirovac Bay is a semienclosed bay located in the shore area of Central Adriatic between Zadar and Šibenik. Savudrija town is positioned at the shore of northern Istra. These three locations are anthropogenically affected by different sources i.e. untreated municipal and industrial sewage from cities, tourist facilities in the summer etc.

European sea bass (Dicentrarchus labrax) were sampled in 2009 with scuba diving and by catching in the farm. In order to determine the element concentration between fish sizes, four various sea bass specimens, 6 to $25.2 \mathrm{~cm}$ in length and 15 to $312.2 \mathrm{~g}$ in wet weight, were collected at fish farms. After sampling, fishes were stored in a cool box and later frozen. In the laboratory, fishes were sectioned and freeze-dried for at least $72 \mathrm{~h}$. Dried samples were homogenized and crushed to a fine powder by grinding in an agate mortar.

Fish tissues were analysed for certain trace metals in a certified Canadian commercial laboratory (ACTLABS: Activation Laboratories Ltd., Ancaster, Ontario, Canada) using inductively coupled plasma mass spectrometry (ICP/MS). Dry, ashed samples were dissolved in acid and analysed by High Resolution ICP/MS. Additionally, a special microwave digestion procedure (closed vessel digestion) was used. The analytical precision and accuracy were within $\pm 10 \%$ for the analysed elements. This was indicated by the results of the duplicate measurements of both fish samples and standards (NIST 1575a and DORM-2).

\section{Results and Discussion}

Measured results show the ranges of element concentrations in sea bass muscles 1.60-4.46 ppm for arsenic, 0.001-0.079 ppm for cadmium, 0.14-49.10 ppm for chromium, 1.38-4.85 ppm for cooper, 0.11-1.31 ppm for mercury, 0.01-0.65 ppm for lead and 21.9-136.0 ppm for zinc. Generally, mean concentrations of $\mathrm{As}, \mathrm{Cd}, \mathrm{Cr}$, $\mathrm{Cu}, \mathrm{Pb}$, and $\mathrm{Zn}$ were higher in cultured fishes, while only $\mathrm{Hg}$ values were higher in wild specimens. The higher general mean content of cultured fish was mainly the result of the concentrations in the smallest sea bass samples. By ignoring the latter samples, the mean values of cultures specimens were mostly below the wild concentrations.

Several studies show that sizes of marine animals play an important role in metal contents in their tissues. Previous investigations established a significant negative relationship between metal concentrations and fish size (Nussey et al., 2000; Canli \& Atli, 2003; Henry et al., 2004). Equally, our results showed generally a negative relationship. The highest metal concentrations were observed in the smallest sea basses and the content of metals decreases with increases in the weight and length of specimens. Thus, for $\mathrm{As}, \mathrm{Pb}$, and $\mathrm{Zn}$ the lowest concentrations were found in the biggest sea bass. The lowest values of $\mathrm{Cd}, \mathrm{Cr}, \mathrm{Cu}$, and $\mathrm{Hg}$ were measured in the medium size sea bass, while the concentrations in the biggest sea bass were again slightly elevated. This negative relationship in our study between metal content and fish size can be explained by the difference in metabolic activity between younger and older fishes as previously described in similar studies (Nussey et al., 2000; Canli \& Atli, 2003).

In order to assess the possible risk for human health, measured values of fish tissues were compared with the limit values proposed by various authorities: the Ministry of Agriculture, Fisheries and Food (MAFF, 2000), the United Nations Food and Agriculture Organization (FAO), which published the "Compilation of Legal limits for Hazardous Substances and Fish and Fishery Products" (Nauen, 1983) and the European Commission (EC, 2001). Mean values of $\mathrm{Cd}, \mathrm{Cu}, \mathrm{Hg}, \mathrm{Pb}$, and $\mathrm{Zn}$ were below the permissible levels in cultured and wild fish specimens, with the exception of $\mathrm{Hg}$ in wild fish samples and $\mathrm{Zn}$ in cultured one, which slightly exceeded them. The mean concentrations of $\mathrm{As}$ and $\mathrm{Cr}$ obtained in cultured and wild fish specimens were higher than those established by the regulations. Arsenic concentrations were at least for little exceeding the permissible levels in practical all samples, chromium was elevated in wild samples and the smallest cultured fish. Among the wild samples, obviously elevated values of $\mathrm{As}, \mathrm{Cr}, \mathrm{Hg}$, and $\mathrm{Zn}$ were measured in fishes collected at Korčula sampling site and also As and $\mathrm{Cr}$ concentrations were higher in Pirovac Bay and Savudrija locations. The elevated values of some metals (As, Cd, Cr, $\mathrm{Zn}$ ) in cultured fishes were observed in the smallest sea basses. Moreover, the values of potentially commercial cultured fishes were practically below the recommended limits with the only little elevation of arsenic.

\section{Conclusion}

If we exclude the smallest cultured sea basses, the concentrations of cultured fish specimens were lower than the wild one, with the exception of cooper. These indicate several different potential natural and anthropogenic sources of elements, such as geologic weathering, fish feed, untreated municipal and industrial sewages, waste from sewage treatment plants, or agricultural waste sewages.

The results of cultured sea basses showed a generally negative relationship between fish size and metal level. Generally, the highest values were observed in smaller fishes and the lowest in the biggest, commercial one.

Mean values of $\mathrm{Cd}, \mathrm{Cu}, \mathrm{Hg}, \mathrm{Pb}$, and $\mathrm{Zn}$ were below the permissible levels in cultured and wild fish specimens, with the exception of $\mathrm{Hg}$ in wild fish samples and $\mathrm{Zn}$ in cultured one. Elevated values of $\mathrm{As}$ and $\mathrm{Cr}$ of cultured samples were high mainly due to the juvenile 
non-commercial sea basses, which also showed elevated concentrations of some other metals ( $\mathrm{Pb}$ and $\mathrm{Zn}$ ). In larger, commercial cultured fish samples only As showed slightly higher concentrations regarding to recommended legal limits and were even lower than in wild one. Consequently investigated fishes from farm present no toxically danger for human consumption.

\section{Acknowledgements}

The research was financially supported by the Ministry of Higher Education, Science and Technology, Republic of Slovenia (Bilateral projects between Croatia and Slovenia 2001-2009), the Slovenian Research Agency (ARRS), and Geoexp, d.o.o., Tržič, Slovenia.

\section{References}

Biladžić N, Đokić $M$, Sedak M. Metal content determination in four fish species from the Adriatic Sea. Food Chemistry 2011; 124: 1005-1010.

Burger J, Gochfeld M, Jeitner C, Burke S, Stamm T. Metal levels in flated sole (Hoppoglossoides elassodon) and great sculpin (Myoxocephalus polyacanthocephalus) from Adak Island, Alaska: Potential risk to predators and fishermen. Environmnetal research 2007; 103: 62-69.

Canli M, Atli G. The relationship between heavy metal $(\mathrm{Cd}, \mathrm{Cr}, \mathrm{Cu}, \mathrm{Fe}, \mathrm{Pb}, \mathrm{Zn})$ levels and the size of six Mediterranean fish species. Environmental pollution 2003; 121: 129-136.

Cid BP, Boia C, Pombo L, Rebelo E. Determination of trace metals I fish species of the Ria de Aveiro (Portugal) by electrothermal atomic absorption spectrometry. Food Chemistry 2001; 75: 93-100.

Commission Regulation (EC) No 466/2001 of 8 March 2001 setting maximum levels for certain contaminants in foodstuffs. Official Journal of the European Communities 2001; L77.

Demirak A, Yilmaz F, LeventTuna A, Ozdemir N. Heavy metals in water, sediment and tissues of Leuciscus cephalus from a stream in southwestern Turkey. Chemosphere 2006; 63; 1451-1458.

Dural M, Göksu MZL, Özak AA. Investigation of heavy metals in economically important fish species captured from Tuzla lagoon. Food Chemistry 2007; 102: 415-421.
Ersoy B, Yanar Y, Küçükgülmez A, Çelik M. Effects of four cooking methods on the heavy metal concentrations of sea bass fillets (Dicentrarchus labrax Linne, 1785). Food Chemistry 2006; 99: 748-751.

Fallah AA, Saei-Dehkordi SS, Nematollahi A, Jafari T. Comparative study of heavy metal and trace element accumulation in edible tissues of farmed and wild rainbow trout (Oncorhynchus mykiss) using ICP-OES technique. Microchemical Journal 2011; 98: 275-279.

Henry F, Amara R, Courcot L, Lacouture D, Bertho M-L. Heavy metals in four fish species from the French coast of the Eastern English Channel and Southern Bight of the North Sea. Environmental International 2004; 30: 675-683.

MAFF (Ministry of Agriculture, Fisheries and Food). Monitoring and surveillance of non-radioactive contaminants of wastes at Sea, 1997. Aquatic Environment Monitoring Report No. 52. Center for Environment Fisheries and Aquaculture Science 2000. Lowestoft, UK.

Mieiro CL, Pacheco M, Duarte AC, Pereira ME. Fish consumption and risk of contamination by mercury - Considerations on the definition of edible parts based on the case study of European sea bass. Marine Pollution Bulletin 2011; 62: 2850-2853.

Nauen CE. Compilation of Legal Limits for Hazardous Substances in Fish and Fishery Products. United Nations Food and Agriculture Organization 1983.

Nussey G, Van Vuren JHJ, du Preez HH. Bioaccumulation of chromium, manganese, nickel and lead in the tissues of the moggel, Labeo umbratus (Cyprinidae), from Witbank dam, Mpumalanga. Water Sea 2000; 26: 269-284.

Percin F, Sogut O, Altınelataman C, Soylak M. Some trace elements in front and rear dorsal ordinary muscles of wild and farmed Bluefin tuna (Thunnus fhynnus L.1758) in Turkish part of the eastern Mediterranean Sea. Food and Chemical Toxicology 2011; 49: 1006-1010.

Uysal K, Köse E, Bülbül M, Dönmez M, Erdogan Y, Koyun M, Ömeroglu Ã, Özmal F. The comparison of heavy metal accumulation ratios of some fish species in Enne Dame Lake (Kütahya/Turkey). Environmental Monitoring and Assessment 2009; 157: 355-362. 